\title{
Acute Anticonvulsant Effect and Toxicity of Senna tora Leaves Extracts in Seizure Test in Mice
}

\author{
Katoucha Sidoine Zouakeu Ngatcha ${ }^{1}$, Elisabeth Ngo Bum ${ }^{1}$, Ur Rehman Nisar ${ }^{2}$, \\ Nicolas Yanou Njintang ${ }^{1, *}$ \\ ${ }^{1}$ Department of Biological Sciences, Faculty of Sciences, University of Ngaoundere, Cameroon \\ ${ }^{2}$ Department of Pharmacy, Comsats University Islamabad, Abbotabad-Campus, Pakistan
}

Email address:

njintang@yahoo.fr (N. Y. Njintang)

${ }^{*}$ Corresponding author

\section{To cite this article:}

Katoucha Sidoine Zouakeu Ngatcha, Elisabeth Ngo Bum, Ur Rehman Nisar, Nicolas Yanou Njintang. Acute Anticonvulsant Effect and Toxicity of Senna tora Leaves Extracts in Seizure Test in Mice. Journal of Diseases and Medicinal Plants. Vol. 6, No. 1, 2020, pp. 1-10. doi: 10.11648/j.jdmp.20200601.11

Received: December 15, 2019; Accepted: January 7, 2020; Published: January 16, 2020

\begin{abstract}
Senna tora leaves are used as traditional medicine in Africa for the treatment of many disorders. In Cameroon, the leaves of this plant are used for the treatment of convulsions and malaria. No work has been interested on the anticonvulsant activity and toxicity of Senna tora as affected by solvent extraction. This study has the objective to evaluate the anticonvulsant activity and toxicity of Senna tora extracts. The extracts were produced by maceration in 4 different solvents (water, ethanol, methanol and hydroethanol) and by decoction. Several doses $(45,112.5,225$ and $450 \mathrm{mg} / \mathrm{kg}$ ) of the five Senna tora extracts were tested for their efficacy against convulsion induced by bicuculin, kainic acid, strychnine and picrotoxin. Normal, negative and positive (phenobarbital and clonazepam treatment) control treatments were equally tested. Firstly, the animal received the treatment (per os), after 1 hour all they animals received the injection of convulsivant solution except normal control. Latency time and duration of convulsion were noted. For acute toxicity, the animals received one dose $(5000 \mathrm{mg} / \mathrm{kg})$ of the different extracts and were observed during 7 days. As results, it appeared that the methanolic, ethanolic and hydroethanolic extract at the dose $450 \mathrm{mg} / \mathrm{kg}$ protected $80 \%$ of mice against convulsion induced by strychnine, picrotoxin. In addition, the plant induced a significant decreased of the duration of convulsions. Moreover, no dead nor toxicity were observed for administration doses less than $5000 \mathrm{mg} / \mathrm{kg}$ body weight. Definitively, Senna tora extracts exhibit anticonvulsant and are not toxic, thus pointing out the use of the plant in the treatment of epilepsy.
\end{abstract}

Keywords: Senna Tora, Convulsion, Picrotoxin, Bicuculin, Strychnine, Kainic Acid

\section{Introduction}

Senna tora Linn. (Caesalpiniaceae) is a small annual herb $1.2 \mathrm{~m}$ in height growing as common weed in tropical areas of Africa and Asia. All the parts of the plant are widely used in the traditional systems of medicine. In particular, the leaves are used as laxative, anti-anthelmintic [1], for the treatment of various skin and cardiac disorders [2]. In Cameroon, the leaves of Senna tora are used traditionally for the treatment of malaria and epilepsy. Epilepsy affects 13 to $15 \%$ of people worldwide [3]. According to the World Health Organization (WHO), about $65-80 \%$ of the world's population in developing countries, because of poverty and lack of access to modern medicine, depend primarily on medicinal plants for their primary health care. The literature revealed the different properties of Senna tora extract: antiplasmodial [4], antioxidant [5], antimicrobial [6], antihepatotoxic [7] and hypolipidemic [8] activities. Studies on the anticonvulsant activity are very scare, specifically the effect of solvent extraction. Then, we formulated our central research question as followed: what is the effect of solvent extraction on the anticonvulsive properties and acute toxicity of Senna tora leaves extracts? Answering this question will help not only to report new data on the efficacy of Senna tora extract against convulsion, but also to select a solvent that is more effective in extracting anticonvulsive compound. This will go a long way enabling the search for more effective antiepileptic 
drugs against epilepsy.

The general objective of this work was to determine the anticonvulsant effects of Senna tora extracts from 4 different solvents on models of acute seizures induced by convulsant substances. In addition, the acute toxicity of the extract was determined.

\section{Materials and Methods}

\subsection{Plant Materials}

Senna tora leaves were collected from Maroua, Far North Cameroon, in June 2015. First identification was made by MAPONGMETSEM Pierre-Marie, botanist at the Department of Biological Sciences, University of Ngaoundere, Cameroon. Then the plant was authenticated at the National Herbarium in Yaounde, Cameroon, to number $7765 / \mathrm{SF} \mathrm{R} / \mathrm{cam}$. The leaves were washed several times with distilled water to remove the traces of impurities. They were then dried at room temperature for 24 hours and coarsely powdered in a mortar.

\subsection{Preparation of Plant Extracts}

The powder $(10 \mathrm{~g})$ was used for decoction with water for $20 \mathrm{~min}$, or for maceration for 24 hours with $100 \mathrm{~mL}$ of four different solvents: 99\% methanol, $95 \%$ ethanol, water (aqueous extract), ethanol/water mixture 1:1 (v/v). The solvents (ethanol and methanol) were evaporated using rotatory evaporator (Buchi rotavapor R-300) and freeze drying (Lustiner) while the water extract was directly removed using freeze drying. The freeze-dried extracts were then powdered using a mortar and used to prepare aqueous solutions of different concentrations for biological analysis $(45 \mathrm{mg} / \mathrm{mL}, 112.5 \mathrm{mg} / \mathrm{mL}, 225 \mathrm{mg} / \mathrm{mL}$ and $450 \mathrm{mg} / \mathrm{mL})$.

\subsection{Animal's Material}

Mus musculus swiss weighing $26 \pm 3 \mathrm{~g}$ were used for induction of convulsion. The animals were provided by animal house of University of Ngaoundere, Cameroon and NIH (National Institute of Healh) of Pakistan. All animals were kept in Plexiglas cages, and under a cycle of 12 hours of light and 12 hours of darkness. The experiments were carried out in accordance with national and international law (reg. No. FWA-IRB00001954). Every effort has been made to reduce the pain and the number of animals used.

\subsection{Induction of Convulsion}

\subsubsection{Induction of Convulsion by Bicuculin}

This test consists of inducing clonic convulsions in the mice by intraperitoneal administration of bicuculin at a dose of $1 \mathrm{mg} / \mathrm{kg}$ within 10 minutes [9]. The bicuculin is injected intraperitoneally one hour after the administration of the different treatments: distilled water for mice of the negative control, phenobarbital at a dose of $20 \mathrm{mg} / \mathrm{kg}$ for the positive control and four different doses of the extracts and the decoction of Senna tora for test lots.

\subsubsection{Induction of Convulsion by Picrotoxine}

This test consists of inducing clonic convulsions in the mice by intraperitoneal administration of the picrotoxin at the dose of $7.5 \mathrm{mg} / \mathrm{kg}[10,11]$, one hour after administration of the various treatments namely the phenobarbital at the dose $20 \mathrm{mg} / \mathrm{kg}$ for the positive control lot, distilled water for the negative control lot and the different doses of the extracts and the decoction for the test lots. Mice that do not convulsed within 15 minutes of observation were considered protected [9].

\subsubsection{Induction of Convulsion by Strychnin}

The test consists to inducing tonic convulsions followed by death within $10 \mathrm{~min}$ in the mice by intraperitoneal injection of strychnine (STR, $2.5 \mathrm{mg} / \mathrm{kg}$ ). The animals (eight mice per batch) were treated one hour before administration of the STR with distilled water $(10 \mathrm{ml} / \mathrm{kg}$, per os $)$ for the negative control group, phenobarbital $(20 \mathrm{mg} / \mathrm{kg})$ for the positive control group and four different doses of Senna tora extracts and decoctions for test groups (45, 112.5, 225 and 450 $\mathrm{mg} / \mathrm{kg}$, per os) for test lots [12-13]. After 10 minutes of observation, mice that did not convulsed or those that convulsed but did not died were said to be protected (Ngo Bum et al., 2001, 2009a).

\subsubsection{Induction of Convulsion by Kainic Acid}

This test consists of inducing generalised convulsions in the mice by intraperitoneal administration of kainic acid at a dose of $1.5 \mathrm{mg} / \mathrm{kg}$ [14] one 1 hour after treatment: distilled water for mice of the negative control, phenobarbital at a dose of $20 \mathrm{mg} / \mathrm{kg}$, clonazepam for the positive control and four different doses of the extracts and the decoction of Senna tora for test lots. Latency times and duration of convulsion were noted during 15 minutes.

\subsection{Acute Toxicity}

The method used was the OECD [15] which consists in choosing a single dose and evaluating the different parameters and determining if the LD50 is lower or higher than the chosen dose. For this the dose $5000 \mathrm{mg} / \mathrm{kg}$ is the dose chosen for this study. A total of 60 mice aged of three months weighing an average of $25 \mathrm{~g}$ were divided into 6 groups of 10 mice each, including 5 males and 5 females, the males and females were putted in different cages. After 5 days of acclimatization in the laboratory, the animals were fasted for 3 hours before treatment. After the individual weighing to determine the volume of the extract solution to be administered, the animals were treated as follows:

a. Group 1 has been treated with distilled water.

b. Groups 2 to 6 were treated with four extracts (aqueous, ethanolic, methanolic and hydroethanolic) and with the decoction of Senna tora leaves at a dose of $5000 \mathrm{mg} / \mathrm{kg}$.

c. The animals thus treated were deprived of water and food during the first three hours post-gavage during which they were observed and the following parameters were evaluated: the number of deaths, the mobility 
(measured by the displacement of the animals in the cage), aggression (resulting from the attack of one mouse with respect to the other), the sensitivity to pain (measured by the reaction of the mouse following the pinching of the tail), the sensitivity to noise (measured by the reaction of the mouse following the emission of a noise) and the condition of the stool. After this time, the animals had free access to drinking water and food. Survivors were then kept for 7 days, during which time weight, daily food and water intake were assessed.

\subsection{Statistical Analysis}

Tests were carried out in triplicate. The parameters measured during the pharmacological tests were expressed as mean \pm standard error on the mean (E. S. M.). The values were compared using the Variance Analysis Test (ANOVA) and when the differences existed, the Turkey and Newman Keuls multiple comparison tests were used to separate them. The exact probability of Fisher was used to compare the average percentages of the parameters obtained in the experiments. From $\mathrm{p} \leq 0.05$, the values were considered significant. The various statistical analyzes of the results were made using the XLSTAT 2007 software.
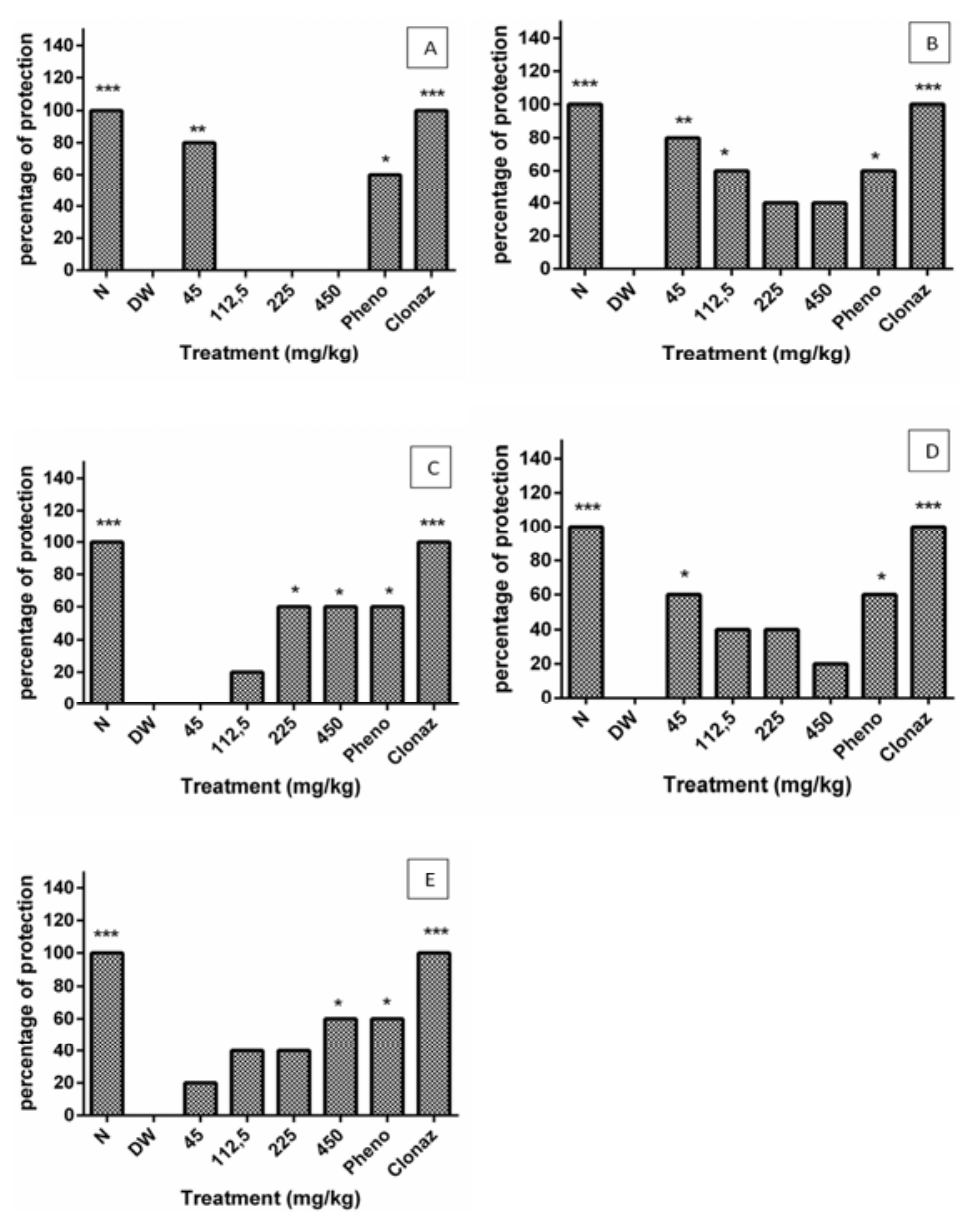

Bars are mean $\pm \mathrm{sd} ; \mathrm{n}=5 ; * * \mathrm{p} \leq 0.001,{ }^{*} \mathrm{p} \leq 0.01$ and ${ }^{*} \mathrm{p} \leq 0.05$ are level of significance as compared to negative control test, N: Neutral, DW: Distilled Water.

Figure 1. Degree of protection (\%) of mice against convulsion induced by picrotoxin as affected by of Senna tora administration dose and extract preparation.

\subsection{Effect of Picrotoxin}

The figure 1 shows that administration of picrotoxin to mice followed by treatment with distilled water induced clonic convulsions to all animal, meaning distilled water (DW) had no protection against clonic convulsions induced by picrotoxin. In contrast, extracts of Senna tora protected mice against convulsions at all doses. In this respect, the decoction and the aqueous extract $(450 \mathrm{mg} / \mathrm{kg}$ ) protected $80 \%(\mathrm{p} \leq 0.01)$ of mice, while the hydroethanolic, ethanolic and methanolic extracts at the same dose protected $60 \%$ of mice. Treatment with Clonazepam and phenobarbital, reference antiepileptic drugs, protected respectively $100 \%$ and $60 \%$ of mice against clonic convulsions induced by picrotoxin. In the meantime, Senna tora extracts significantly increased the latency of onset of convulsions (Figure 2) compared to the negative control and significantly reduced the duration of convulsions (Figure 3) compared to positive control batches that received two reference substances. Picrotoxin is a selective inhibitor of the opening of the GABAA receptor chloride channel whose binding site is located within the chloride channel in the cerebral cortex.

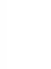

\section{Results and Discussion}




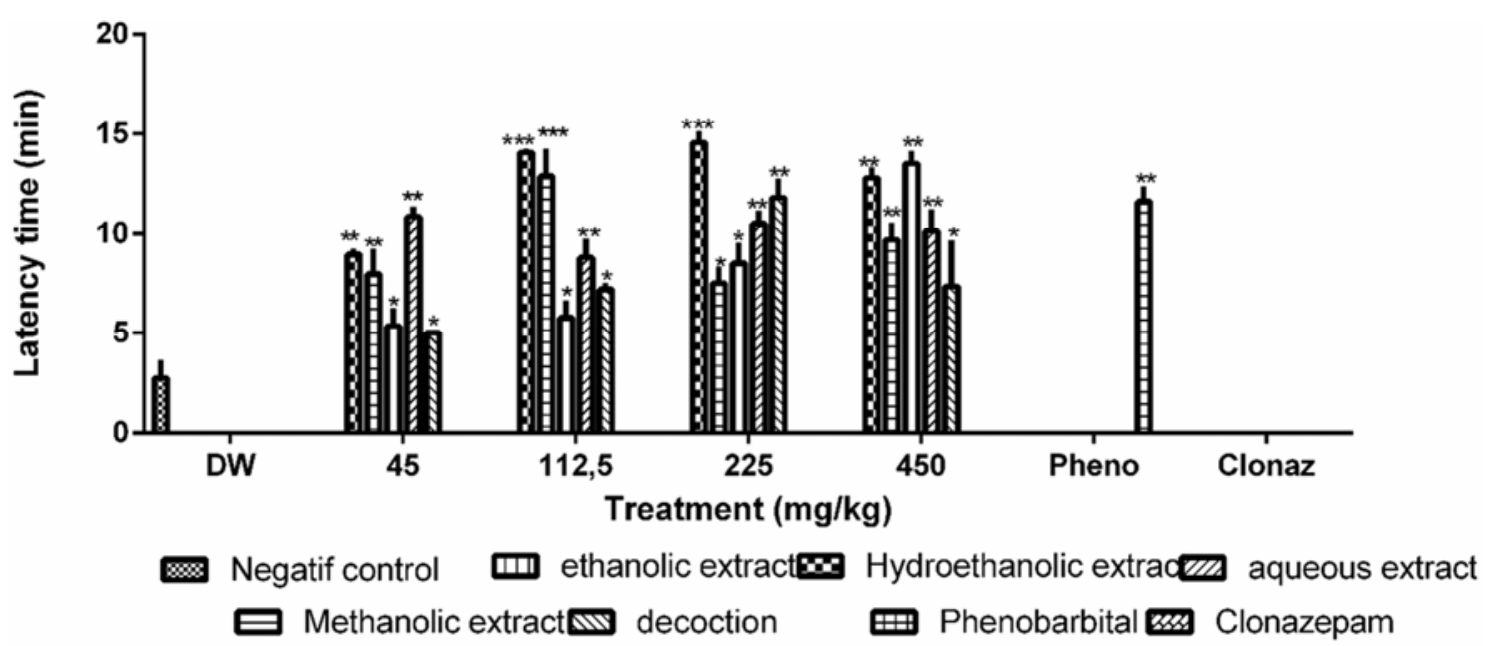

Bars are mean $\pm \mathrm{sd} ; \mathrm{n}=5 ; * * * \mathrm{p} \leq 0.001, * * \mathrm{p} \leq 0.01$ and $* \mathrm{p} \leq 0.05$ are level of significance as compared to negative control, DW: Distilled Water.

Figure 2. Latency time (min) of convulsion of mice in picrotoxin model of convulsion as affected by Senna tora administration dose and extract preparation.

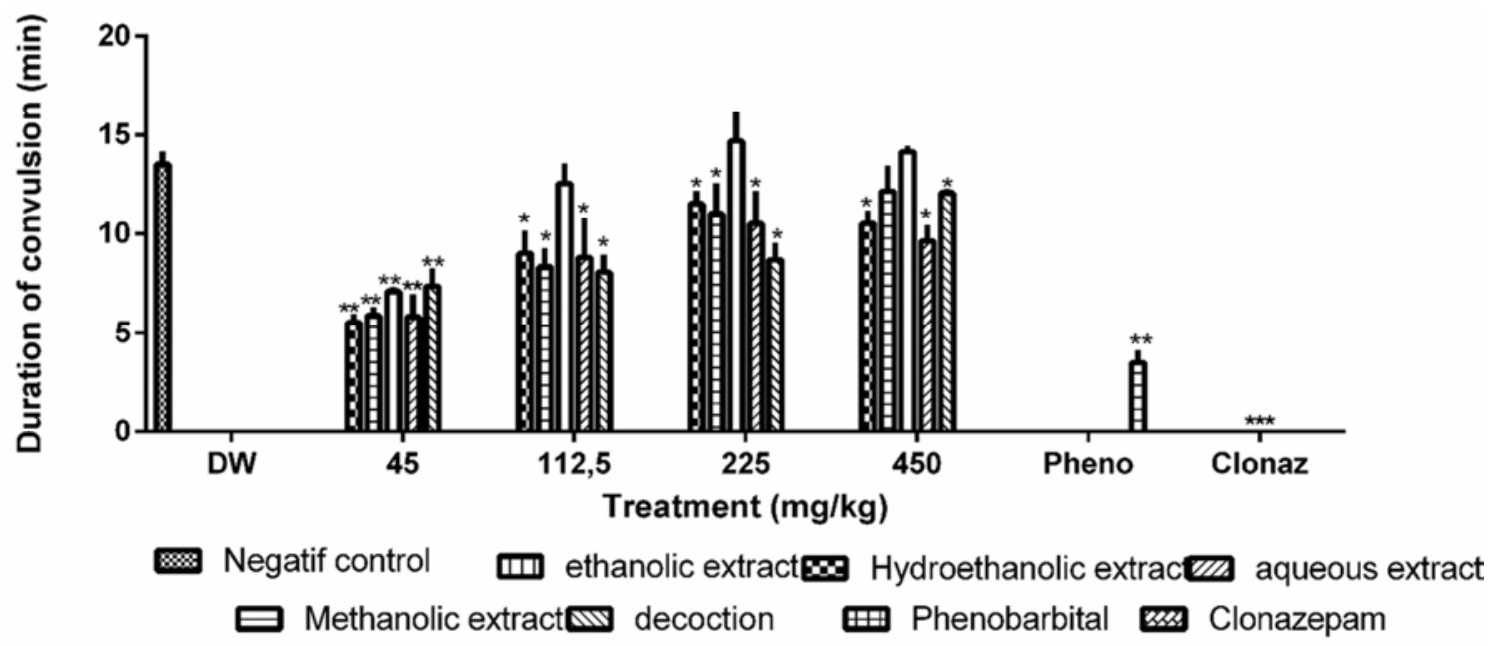

Bars are mean $\pm \mathrm{sd} ; \mathrm{n}=5 ; * * * \mathrm{p} \leq 0.001,{ }^{* *} \mathrm{p} \leq 0.01$ and ${ }^{*} \mathrm{p} \leq 0.05$ are level of significance as compared to negative control, DW: Distilled Water.

Figure 3. Duration of convulsion (min) of mice in picrotoxin model of convulsion as affected by Senna tora administration dose and extract preparation.

Picrotoxin is a selective inhibitor of the opening of the GABAA receptor chloride channel whose binding site is located within the chloride channel in the cerebral cortex. The antagonism of molecules in the extracts with picrotoxininduced convulsions suggests anticonvulsant properties that would be mediated by GABA receptors. Indeed, picrotoxin is known to be a GABA receptor antagonist, it acts by blocking chloride channels bound to GABAA receptors [16, 17]. In addition, potentiation of the effect of clonaz $(0.1 \mathrm{mg} / \mathrm{kg})$ by the highest dose $(450 \mathrm{mg} / \mathrm{kg}$ ) of the extracts would support the idea that the Senna tora would act via GABA receptors because this effect is found potentiated by the benzodiazepine. The protection of mice against picrotoxin induced convulsions suggests that chemical compounds contained in these different Senna tora extracts act as antagonists of picrotoxin (chloride channel blocker) on GABAA receptors [18].

\subsection{Effect of Bicuculin}

The figure 4 shows that injection of bicuculin to mice induced tonic-clonic convulsions and treatment with distilled water (DW) had no protection effect. In contrast, extracts of Senna tora protected at some degree mice against convulsions. While the decoction $(450 \mathrm{mg} / \mathrm{kg})$ protected $80 \%(\mathrm{p} \leq 0.01)$ of mice, the aqueous, hydroethanol, ethanolic and methanolic extracts at the same dose protected $60 \%$ of mice. The reference drugs, Clonazepam and phenobarbital, protected respectively $100 \%$ and $60 \%$ mice. Significant increase of the latency of onset of convulsions (Figure 5) and significant decrease of the duration of convulsions (Figure 6) were equally reported as an effect Senna tora administration as compared to the negative and positive control groups. 


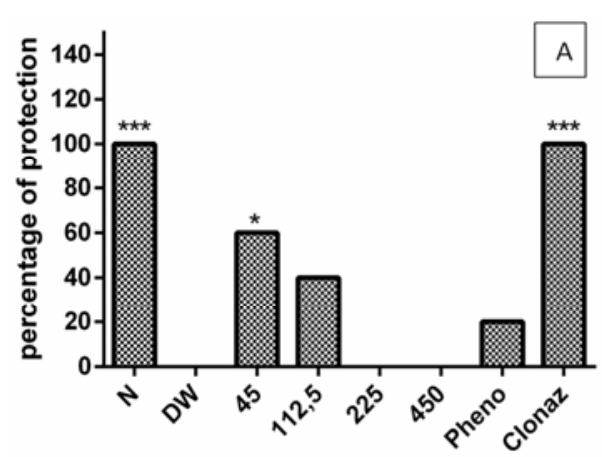

Treatment $(\mathrm{mg} / \mathrm{kg})$
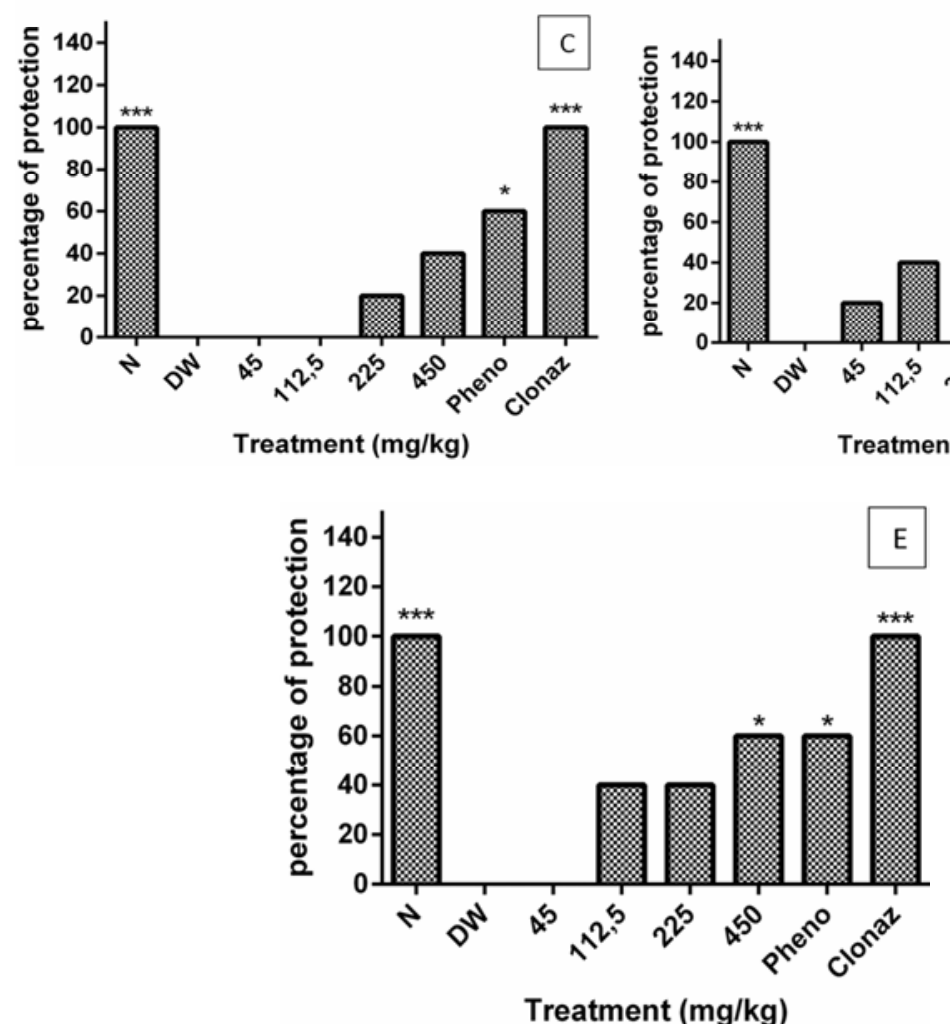

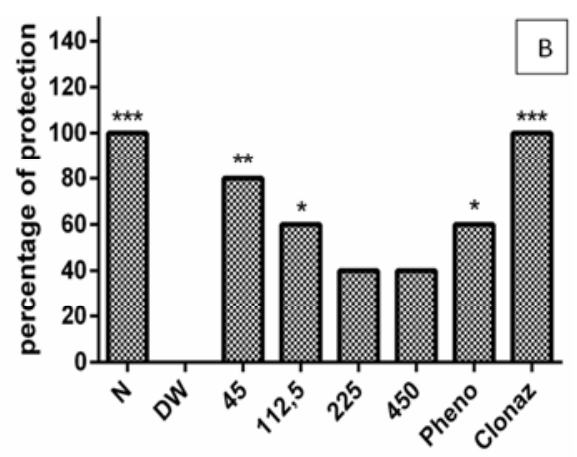

Treatment (mg/kg)

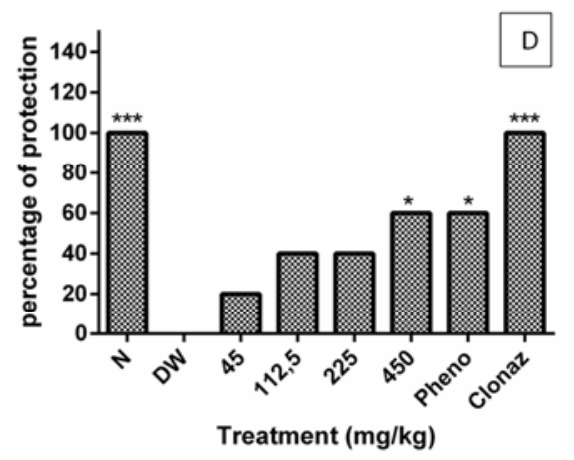

Bars are mean $\pm \mathrm{sd} ; \mathrm{n}=5 ;{ }^{* *} \mathrm{p} \leq 0.001,{ }^{*} \mathrm{p} \leq 0.01$ and ${ }^{*} \mathrm{p} \leq 0.05$ are level of significance as compared to negative control test, N: Neutral, DW: Distilled Water. Figure 4. Degree of protection (\%) of mice against convulsion induced by bicuculin as affected by of Senna tora administration dose and extract preparation

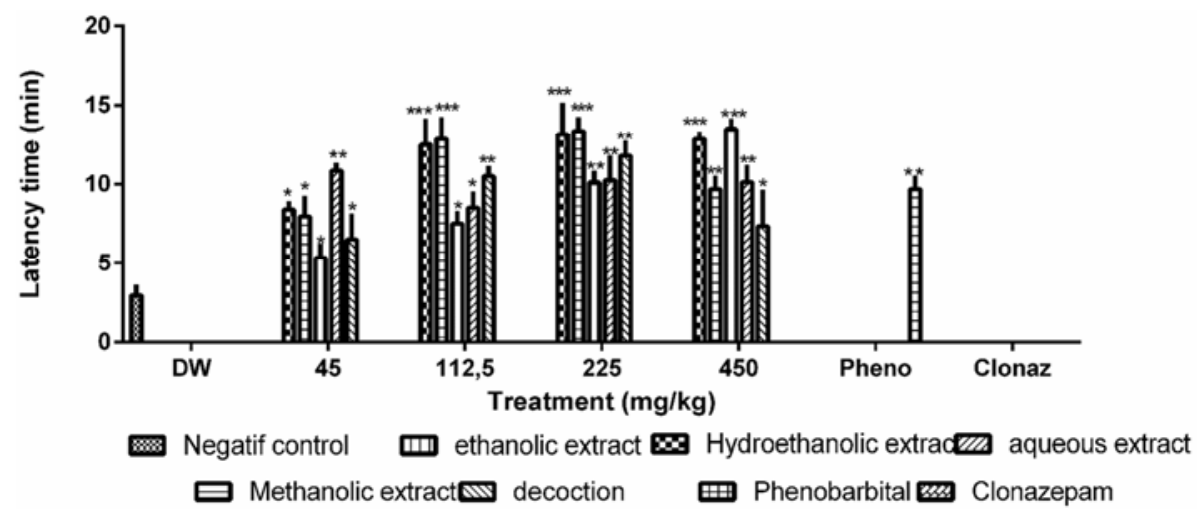

Bars are mean $\pm \mathrm{sd} ; \mathrm{n}=5 ; * * * \mathrm{p} \leq 0.001,{ }^{* *} \mathrm{p} \leq 0.01$ and ${ }^{*} \mathrm{p} \leq 0.05$ are level of significance as compared to negative control, DW: Distilled Water.

Figure 5. Latency time (min) of convulsion of mice in bicuculin model of convulsion as affected by Senna tora administration dose and extract preparation. 


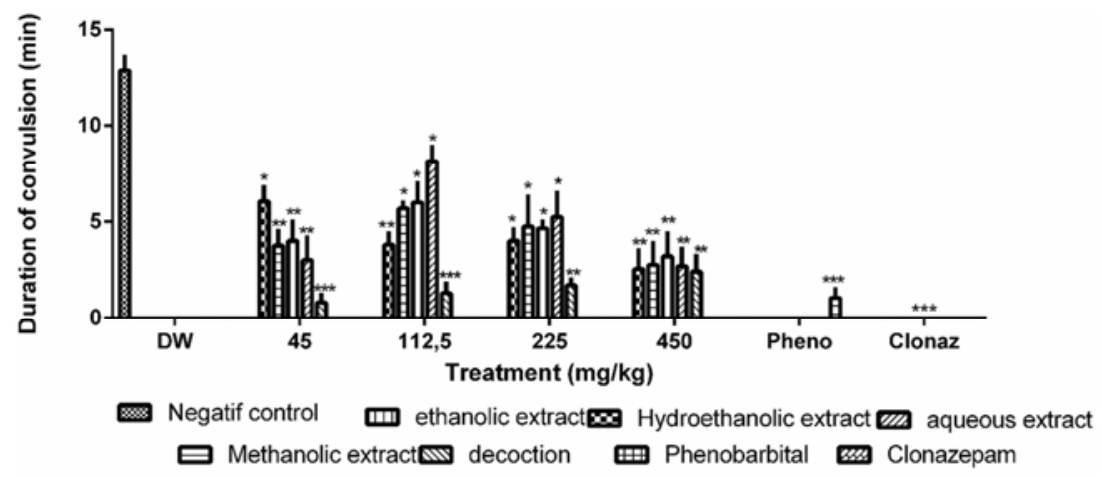

Bars are mean $\pm \mathrm{sd} ; \mathrm{n}=5 ;{ }^{* *} \mathrm{p} \leq 0.001,{ }^{* *} \mathrm{p} \leq 0.01$ and ${ }^{*} \mathrm{p} \leq 0.05$ are level of significance as compared to negative control, DW: Distilled Water.

Figure 6. Duration of convulsion ( $\mathrm{min}$ ) of mice in bicuculin model of convulsion as affected by Senna tora administration dose and extract preparation.

Extracts of Senna tora inhibited convulsions induced by bicuculin. This inhibition also makes it possible to foresee the presence of the anticonvulsant properties in the extracts. In this case once more, the inhibitory action of Senna tora extracts would probably be by interaction of its constituents with GABAergic neurotransmission, mediated by the GABAA receptor complex $[19,20]$. The probable hypothesis of the action of the extracts at the level of the GABA receptor complex is confirmed by the different results of the tests of induction of convulsions by picrotoxin and bicuculin, which are all substances acting on the GABAergic neurotransmission. The presence of certain bioactive compounds such as alkaloids, flavonoids, polyphenols and tannins in the extracts of this plant could explain at least in part the anticonvulsant effects because phenolic compounds have been demonstrated to reduce the number and duration of seizures in the model of acute attacks induced in mice [21].

\subsection{Effect of Strychnin}

The figure 7 shows that distilled water did not protected mice against strychnine-induced tonic convulsions. However, the different extracts of Senna tora significantly $(\mathrm{p}<0.05)$ protected mice against strychnine-induced convulsions in a dose-dependent manner. This protection was very significant for all the extracts used at the doses 225 and $450 \mathrm{mg} / \mathrm{kg}$.

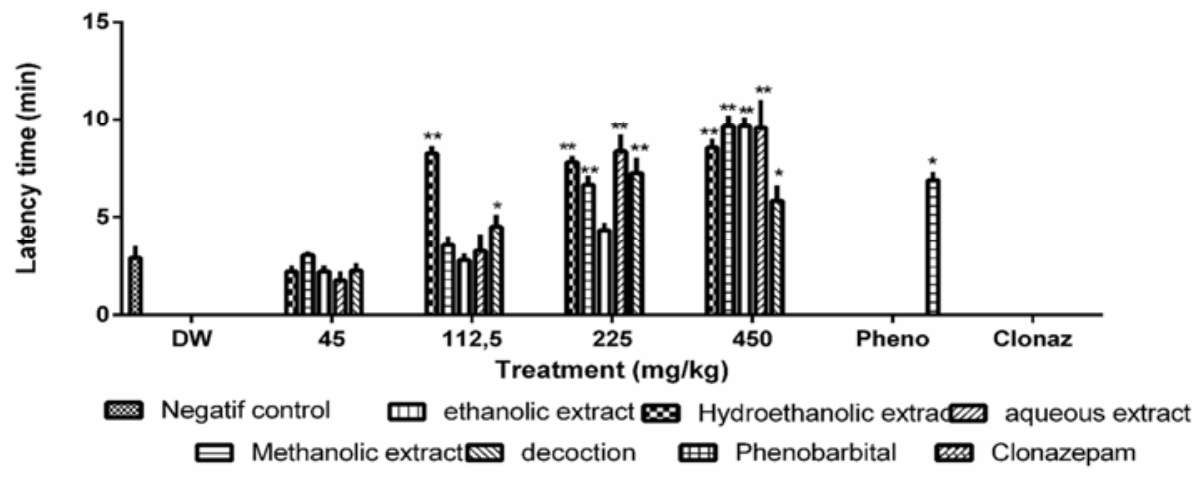

Bars are mean $\pm \mathrm{sd} ; \mathrm{n}=5 ; * * \mathrm{p} \leq 0.001, * * \mathrm{p} \leq 0.01$ and ${ }^{*} \mathrm{p} \leq 0.05$ are level of significance as compared to negative control, DW: Distilled Water.

Figure 8. Latency time (min) of convulsion of mice in strychnin model of convulsion as affected by Senna tora administration dose and extract preparation.

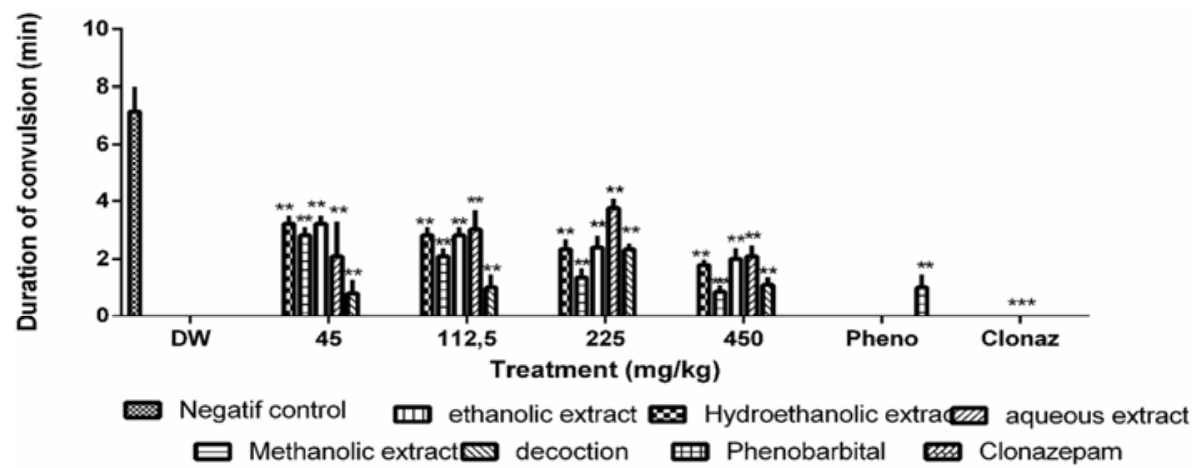

Bars are mean $\pm \mathrm{sd} ; \mathrm{n}=5 ; * * * \mathrm{p} \leq 0.001,{ }^{* *} \mathrm{p} \leq 0.01$ and ${ }^{*} \mathrm{p} \leq 0.05$ are level of significance as compared to negative control, DW: Distilled Water.

Figure 9. Duration of convulsion (min) of mice in strychnin model of convulsion as affected by Senna tora administration dose and extract preparation. 


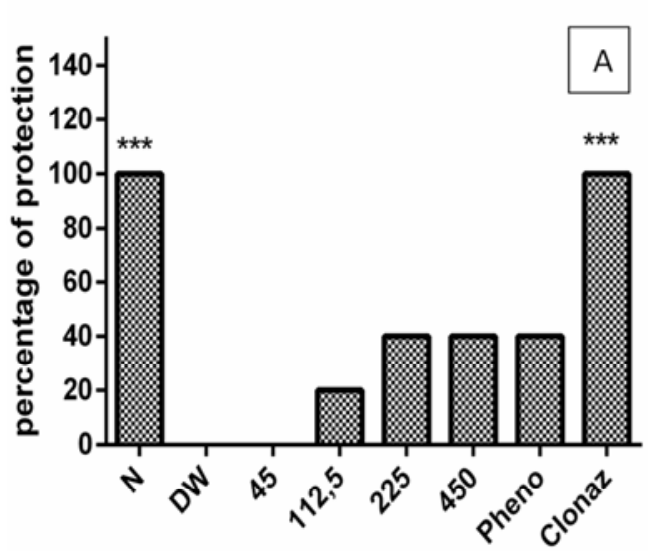

Treatment $(\mathrm{mg} / \mathrm{kg})$

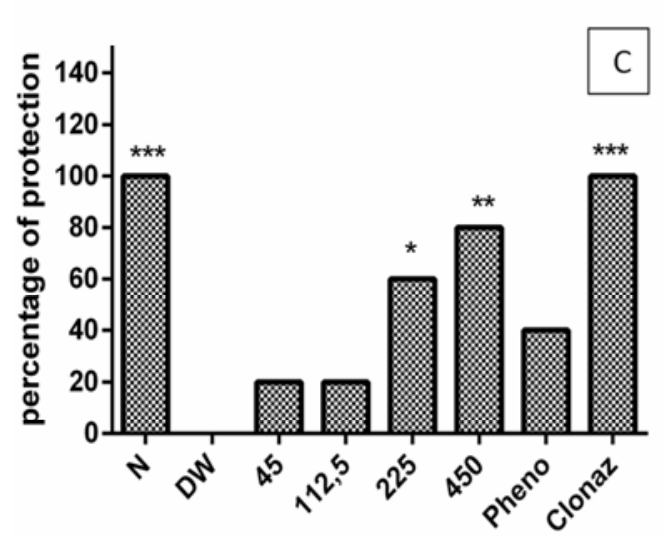

Treatment $(\mathrm{mg} / \mathrm{kg})$

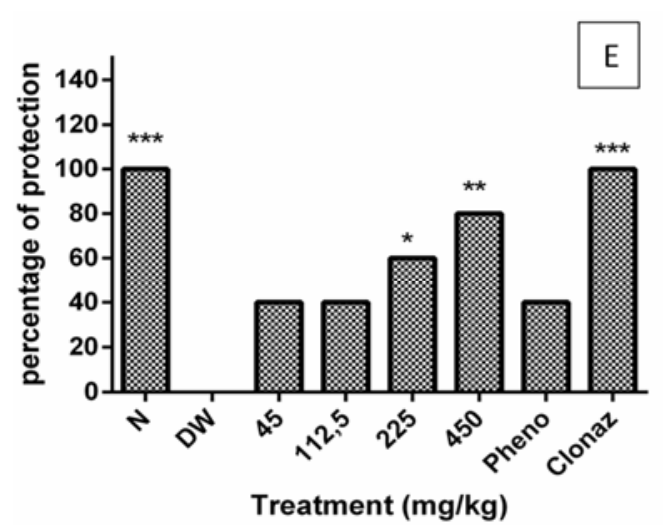

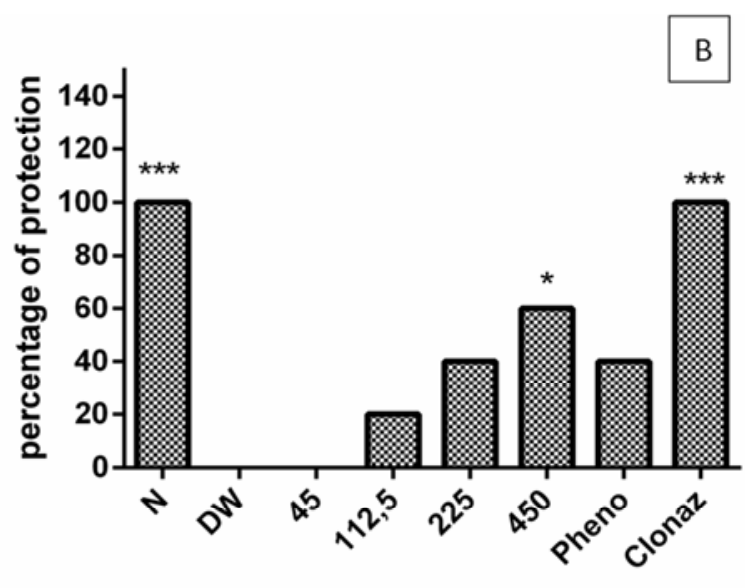

Treatment (mg/kg)

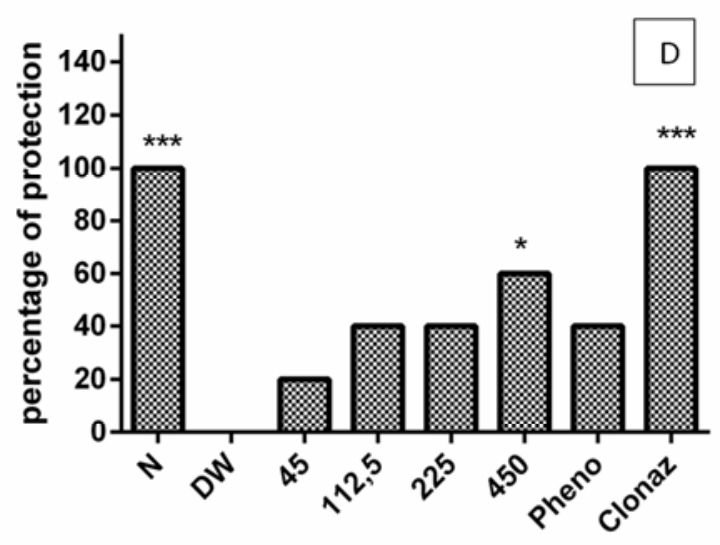

Treatment $(\mathbf{m g} / \mathbf{k g})$

Bars are mean $\pm \mathrm{sd} ; \mathrm{n}=5 ; * * * \mathrm{p} \leq 0.001,{ }^{* *} \mathrm{p} \leq 0.01$ and ${ }^{*} \mathrm{p} \leq 0.05$ are level of significance as compared to negative control test, N: Neutral, DW: Distilled Water.

Figure 7. Degree of protection (\%) of mice against convulsion induced by strychnin as affected by of Senna tora administration dose and extract preparation.

The results of the strychnine test confirmed amongst others that Senna tora extracts have anticonvulsant properties since a substance that protects mice against strychnine-induced tonic convulsions and death is anticonvulsant [12]. This protection, which was similar to that of the reference anticonvulsants (phenobarbital and clonazepam), once again suggests the presence of anticonvulsant compounds in the extracts [22, 23]. Indeed, according to Goth [24], the substances which opposed the effect of strychnine are anticonvulsants, and they act at the level of glycine receptors. Strychnine is a glycine antagonist, its attachment to the glycine receptor leads to an increase in the excitability of the cell which results in hyper reactivity to stimuli. In this case the anticonvulsant action of the extracts would be through an interaction with strychnine-dependent glycine [25, 10]. Considering the significant percentage at doses 225 and 450 $\mathrm{mg} / \mathrm{kg}$, the effect of the extracts suggested that the plant would have antiepileptic activity through interaction with the 
receptor Gaba A chloride channel [26] and with strychninedependent glycine receptors $[25,10]$.

\subsection{Effect of Kainic Acid}

Figure 10 shows the percentage of convulsions induced by kainic acid. It appears that the $450 \mathrm{mg} / \mathrm{kg}$ dose of the decoction and the methanolic extract protected the mice at $80 \%$ compared to the negative control. These results are superior to the protection $60 \%$ induced by the reference substance clonazepam. Figure 11 and 12 shows the latency times and the duration of the convulsions of the mice induced by the administration of kainic acid. From this figure, it appears that the administration of the different extracts of Senna tora induced significant reduction of the duration of convulsions and increase of the latency time compared to the negative control. These results suggested that Senna tora extracts exhibited anticonvulsant effects through interaction with glutamatergic neurotransmission. The results clearly showed that administration of Kainic acid induced tonicclonic convulsions in mice treated with distilled water. In addition, treatment of the mice with Senna tora extracts and sodium valproate protected the mice from these tonic-clonic seizures. Such as sodium valproate, Senna tora extract may exert its anticonvulsant properties by the inhibition of the exocytosis of L-glutamate (blockage of voltage-dependent sodium and calcium channels). Indeed, it is known that kainic acid (glutamate agonist) induces and cell loss in the CA1 and CA2 regions by stimulating massive exocytosis of L-glutamate in the synaptic cleft. However, inhibition of this exocytosis results in the cessation of convulsions [27, 28], in this case, several mechanisms are involved (blockage of sodium and calcium channels voltage dependent).
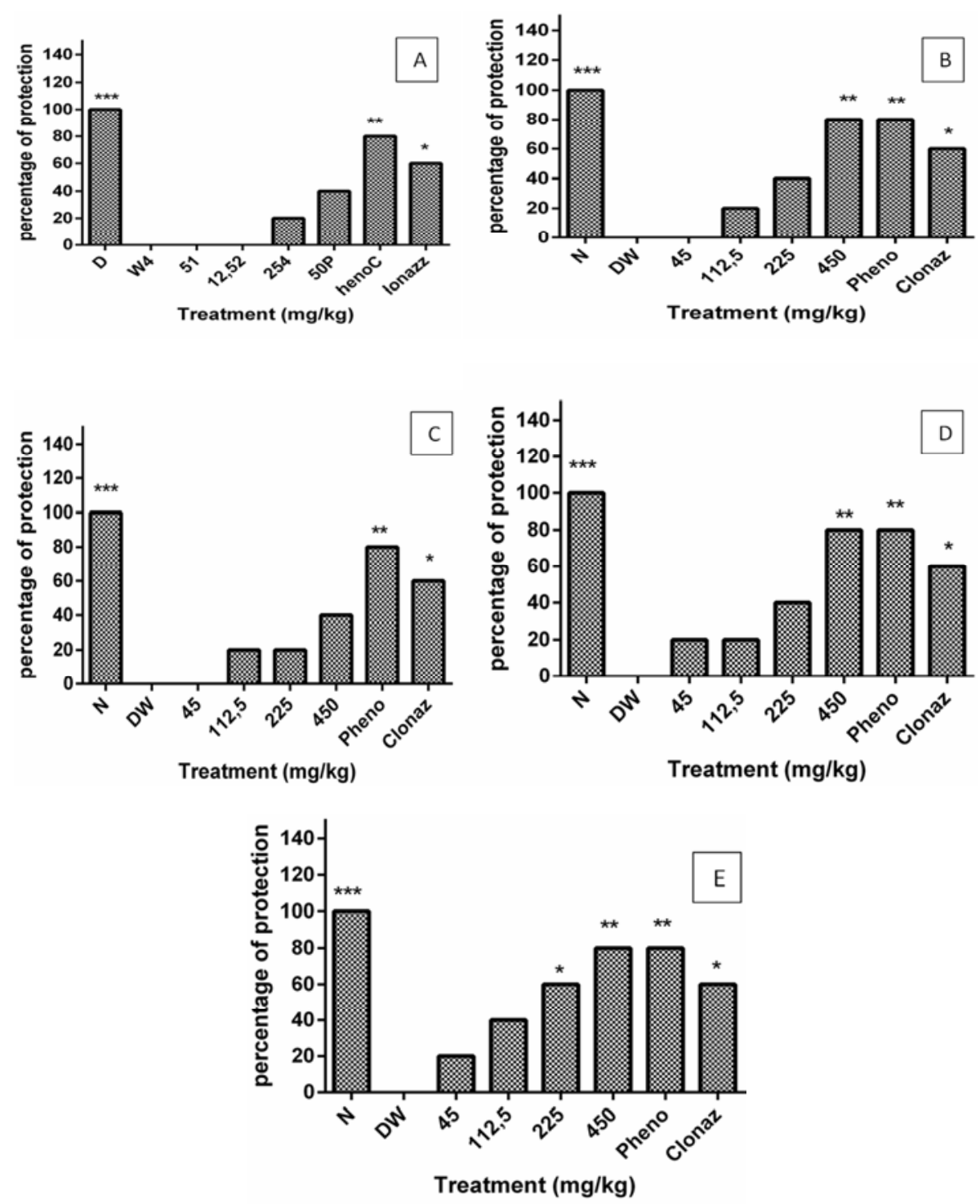

Bars are mean $\pm \mathrm{sd} ; \mathrm{n}=5 ; * * * \mathrm{p} \leq 0.001,{ }^{* *} \mathrm{p} \leq 0.01$ and $* \mathrm{p} \leq 0.05$ are level of significance as compared to negative control test, N: Neutral, DW: Distilled Water.

Figure 10. Degree of protection (\%) of mice against convulsion induced by kainic acid as affected by of Senna tora administration dose and extract preparation. 


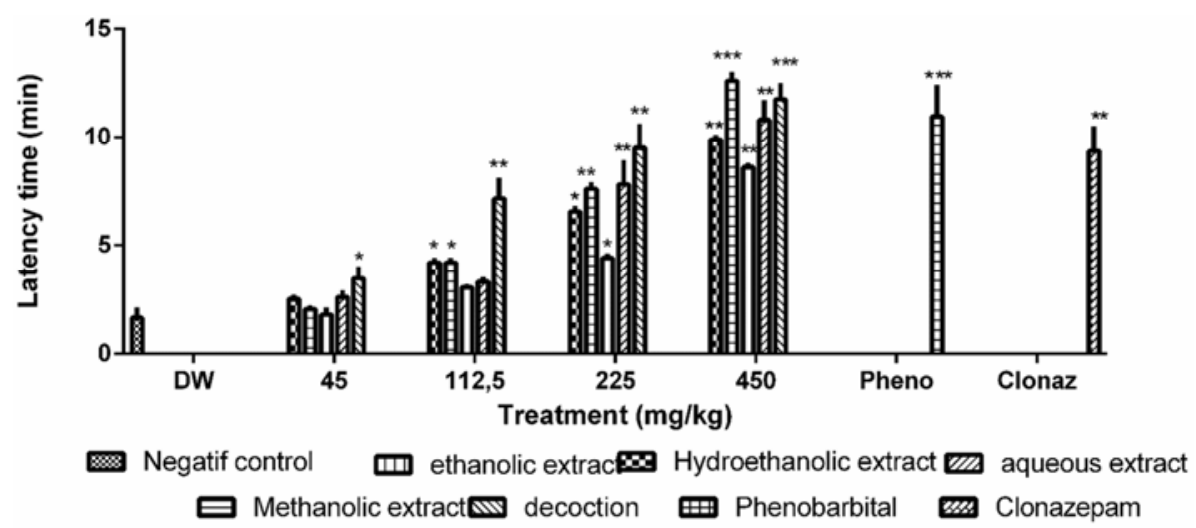

Bars are mean $\pm \mathrm{sd} ; \mathrm{n}=5 ;{ }^{* *} \mathrm{p} \leq 0.001,{ }^{* *} \mathrm{p} \leq 0.01$ and ${ }^{*} \mathrm{p} \leq 0.05$ are level of significance as compared to negative control, DW: Distilled Water.

Figure 11. Latency time (min) of convulsion of mice in kainic acid model of convulsion as affected by Senna tora administration dose and extract preparation.

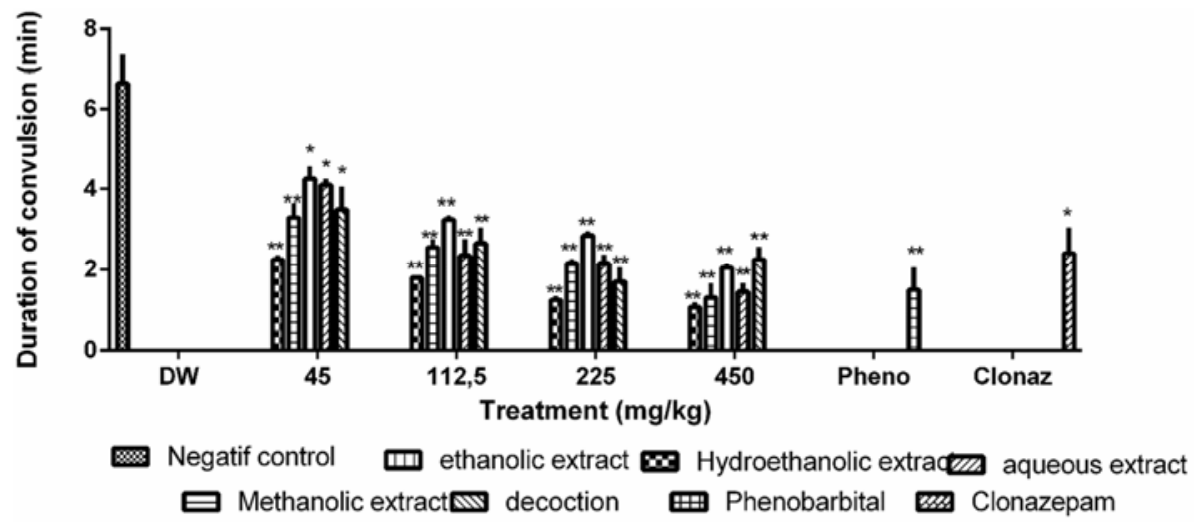

Bars are mean $\pm \mathrm{sd} ; \mathrm{n}=5 ; * * * \mathrm{p} \leq 0.001, * * \mathrm{p} \leq 0.01$ and ${ }^{*} \mathrm{p} \leq 0.05$ are level of significance as compared to negative control, DW: Distilled Water.

Figure 12. Duration of convulsion (min) of mice in kainic acid model of convulsion as affected by Senna tora administration dose and extract preparation.

\subsection{Acute Toxicity}

After oral administration of Senna tora at the dose of $5000 \mathrm{mg} / \mathrm{kg}$, no death was recorded and this throughout the 7 days of observations, meaning the LD50 and LD100 if existed are over the dose $5000 \mathrm{mg} / \mathrm{kg}$ (Table 1). Meanwhile the sensitivity and locomotor activity of the mice of the batch having received the methanolic extract decreased significantly $(p<0.05)$ compared to the control lot which did not received distilled water. Only the mice that received the methanolic extract at dose $5000 \mathrm{mg} / \mathrm{kg}$ showed some physiological changes.

Table 1. Some physiological changes in mice administered Senna tora in acute toxicity study.

\begin{tabular}{llllll}
\hline \multirow{2}{*}{ Extracts } & \multirow{2}{*}{ Doses $(\mathbf{m g} / \mathbf{k g})$} & \multirow{2}{*}{ Physiological changes } & \multirow{2}{*}{ Latency time of mortality } & \multicolumn{2}{c}{ Mice dead/Mice treated } \\
\cline { 5 - 6 } & & No & $/$ & $0 / 5$ & $0 / 5$ \\
Distilled water & & No & $/$ & $0 / 5$ & $0 / 5$ \\
Decoction & 5000 & No & $/$ & $0 / 5$ & $0 / 5$ \\
Aqueous E. & 5000 & No & $/$ & $0 / 5$ & $0 / 5$ \\
Hydroethanolic E. & 5000 & Aggressivity, salivation & $/$ & $0 / 5$ & $0 / 5$ \\
Methanolic E. & 5000 & No & $/$ & $0 / 5$ & $0 / 5$ \\
Ethanolic E. & 5000 &
\end{tabular}

In overall, toxicity studies have shown that the extracts and decoction of Senna tora would not be toxic up to dose 5000 $\mathrm{mg} / \mathrm{kg}$. In this respect, these extracts may be considered as low toxicity substances.

\section{Conclusion}

The main objective of the present study conducted with extracts and decoction of Senna tora in various solvents was to evaluate primary their efficacy on convulsions induced using different chemical substances namely picrotoxin, bicuculin, strychnine and kainic acid induced acute convulsion in mice, in the quest for bringing a solution test to the prevention of epilepsy; secondly to evaluated their eventual acute toxicity. It may be concluded from this study that Senna tora extracts and decoction prevent against convulsion observed in acute epileptic seizure. The most efficacy extract was decoction. The extract may act by interacting as a ligand on the Gaba A channel receptor and the glycine receptors in the hippocamp of the brain, but this need to be deeply investigated. Pretreatment with 
clonazepam or phenobarbital has been shown to prevent acute convulsion induced.

\section{Acknowledgements}

The authors acknowledged the TWAS to offering the first author a travel grant and a living allowance in Pakistan for the execution of this work. We also wish to acknowledge the members of the CAMSATS Institute of Information Technology (CIIT) of Abbottabad, Pakistan for their collaboration.

\section{References}

[1] Samanta A, Ganguly S, Hashimoto H, Devadiga S, Vermote E, Knyazikhin Y, Nemani RR, Myneni RB. Amazon forests did not green-up during the 2005 drought. Geophys Res Lett. 2010; 37: doi: 10.1029/2009GL042154.

[2] Meena AK, Niranjan US, Yadav AK, Singh B, Nagariya AK, Rao MM. Cassia tora Linn, 2010. A review on its ethnobotany, phytochemical and pharmacological profile. J Pharm Res 3 (3): $557-560$.

[3] OMS. (2016). Epilepsy: aetiology, epidemiology, causes and treatments, WHO Fact Sheet, No. 992.

[4] El-Tahir A, Satti GM, Khalid SA: Antiplasmodial activity of selected sudanese medicinal plants with emphasis on Acacia nilotica. Phytother Res 1999, 13 (6): 474-478.

[5] Prabhu A, Krishnamoorthy M: antioxidant activity of ethanolic extract of cassia tora L. Int $J$ Res Ayurveda Pharm 2011, 2 (1): 250-252.

[6] Shaita O: correlation of Hepatoprotective and Antioxidant Effect of Cassia tora Root extract. Master thesis, University of Health Sciences, Bangalore, India, 2005.

[7] Dhanasekaran M, Ignacimuthu S, Agastian P: Potential hepatoprotective activity of ononitol monohydrate isolated from Cassia tora L. on carbon tetrachloride induced hepatotoxicity in wistar rats. Phytomedicine 2009, 16 (9): 891-895.

[8] Tzeng TF, Lu HJ, Liou SS, Chang CJ, Lui IM: Reduction of lipid accumulation in white adipose tissues by Cassia tora (Leguminosae) seed extract is associated with AMPK activation. Food Chem 2013, 136 (2): 1086-1094.

[9] Ngo Bum E., G. S. Taiwe, Moto F. C. O., Ngoupaye G. T., and Nkantchoua G. C. N., Pelanken M. M., Rakotonirina S. V., Rakotonirina A. 2009. Anticonvulsant, anxiolytic, and sedative properties of the roots of Nauclealatifolia Smith in mice. Epilepsy and Behavior, 15: 434-440.

[10] Ngo Bum E., Dawack L., Schmutz M., Rakotonirina. S. V., Portet C., Olpe. H-R and Herling P., 2005. Anticonvulsant activity of Mimosa pudica decoction. Fitoterapia, 75: 310-315.

[11] Ngo Bum., G. S. Taiwe., F. C. O. Moto., G. T. Ngoupaye., G. C. N. Nkantchoua., M. M. Pelaken., S. V. Rakotonirina and A. Rakotonirina., 2009b. Anticonvulsivant, anxiolytics and sedative of the roots of Nauclea latifolia Smith in mice. Epilepsie and Behavior, 15: 434-440.

[12] Ngo Bum, E., Schmutz, M., Meyer, C., Rakotonirina, A., Bopelet, M., Portet, C., Herrling, P. (2001). Anticonvulsant properties of the methanolic extract of Cyperus articulatus (Cyperaceae).
Journal of Ethnopharmacology, 76 (2), 145-150.

[13] Ngo Bum, E., Taiwe, GS., Nkainsa, LA., Moto, FCO., Etet, P. S., Hiana, I. R., Rakotonirina, S. V. (2009a). Validation of anticonvulsant and sedative activity of six medicinal plants. Epilepsy and Behavior, 14 (3), 454-458.

[14] Nadler JV 2003. The recurrent mossy fiber pathway of the epileptic brain. Neurochemical Research, 28: 1649-1658

[15] O. E. C. D., Guidance document on acute oral toxicity, Environmental health and safety monograph series on testing and assessment, $\mathrm{n}^{\circ} 24,(2000)$.

[16] Rang H. P., Dale M. M., Ritter J. M., (2005) Pharmacology. $4^{e}$ edition. Pp 463-481.

[17] Karunakar Hegde, Shalin P Thakker, Arun B Joshl, CS Shastry, KS Chzndrzshekhar (2009), Anticonvulsivan Activity of Carissa carandas Linn. Root Extra in Extract in Experimental Mice, Tropical Journal of Pharmaceutical Research, 8 (2): 117-125.

[18] Mustafa AMS, Ali AM., (2008) Substance in broad beans (Viciafaba) is protective against experimentally induced mice convulsions in mice. Epilepsy Behav. 12, Pp 25-29.

[19] Ngo Bum E, Nkantchoua GN, Njikam N, Taiwe GS, Ngoupaye GT, Pelaken MM, Nanga, Maidawa F, Rakotonirina A: Anticonvulsivant and sedative activity of leaves of senna spectabilis in mice. Int J pharm 2010, 6 (2): 123-128.

[20] Perez-saad, Buznego MT. 2008. Behavior and antiepileptic effets of acute administration of extract of the plant Cestrum nocturnum Lin (Lady of the night). Epilepsy Behav; 12: 366-372.

[21] Ngo Bum E, Ngah E, Mune RN, Minkoulou DZ, Talla E, Moto FCO, Rakotonirina SV: Decoctions of Bridelia micrantha and Croton macrostachyus may have anticonvulsant and sedative effects. Epilepsy Behavior 2012, 24 (3): 319-323.

[22] Pack A. M., Gidal B. E., 2007. Long term adverse events. In: Engel J. Jr., Pdley T. A., editions. Epilepsy: a comprehensive textbook. 2: 1209-1212.

[23] Trailovic S. M., and V. M. Varagic, 2007. The effect of invermectin on convulsions in rats producted by lidocaine and strychnine. Vet res. Commun, 363-872.

[24] Goth A. 1984. Medical Pharmacology, $11^{\text {th }}$ Edition Mosby, St Louis, USA. 815 p.

[25] Findlay G. S., Wick M. J., Mascia M. P., Wallace D., Millier G. W., Harris R. A. and Blednov Y. A., 2002. Transgenic expression of a mutant glycine receptor decreases alcohol sensitivity of mice. Journal of Pharmacology and Experimental Therapeutics 300, 526-534.

[26] Gies J-P., 1993. Bases de pharmacologie moléculaire. Edition ellipses, $160 \mathrm{p}$.

[27] Cavalheiro, E. A., Fernandes, M. J., Turski, L., NaffahMazzacoratti, M. G. (1994). Spontaneous recurrent seizures in rats: amino acid and monoamine determination in the hippocampus. Epilepsia, 35 (1), 1-11.

[28] Williams P. A., Hellier J. L., White A. M., Staley K. J and Dudek F. E., 2009. Development of spontaneous seizures after experimental status epilepticus: implications for understanding epileptogenesis. Epilepsia, 48 (5): 157-163. 